\title{
KVALITETA PROIZVODA KAO ČIMBENIK STVARANJA MARKE
}

\author{
Saša $\operatorname{Petar}^{21} \&$ Tajana Marušićc 22
}

UDK / UDC: 658.626:338.518

JEL klasifikacija / JEL classification: M31, L15

DOI: https://doi.org/10.22598/pi-be/2019.13.2.203

Pregledni znanstveni rad / Scientific review

Primljeno / Received: 20. svibnja 2019. / May 20, 2019

Prihvaćeno za tisak / Accepted for publishing: 21. listopada 2019. / October 21, 2019

\section{Sažetak:}

Odnos marki i potrošača je kompleksan i osjetljiv jer marke često odražavaju mišljenja i stavove potrošača. Potrošači uspostavljaju odnos temeljen na emocijama s mrakom i očekuju da se određene njima važne karakteristike koje povezuju s markom ne mijenjaju. Posebice očekuju kontinuitet u kvaliteti koja se pokazala kao jedna od ključnih odrednica u izgradnji uspješne marke. Na današnjem iznimno brzom i konkurentnom tržištu, za marke je važnije nego ikada da zadrže kontinuitet kvalitete $i$ time ispune očekivanja potrošača. Cilj ovog rada je pobliže objasniti karakteristike marke, kao $i$ razliku između marke i proizvoda te pojasniti sami proces stvaranja marke. Pregledom dostupne $i$ aktualne literature, ovim radom želi se također pobliže istražiti utjecaj kvalitete na stvaranje uspješne marke, a samim time $i$ pozitivnih poslovnih rezultata $i$ profita.

Ključne riječi: marka, proizvod, kvaliteta.

${ }^{21}$ doc.dr.sc Saša Petar, docent, Sveučilište Sjever, Koprivnica, E-mail: spetar@unin.hr

${ }^{22}$ Tajana Marušić, mag.oec., predavač, Sveučilište Sjever, Koprivnica, E-mail: tmarusic@unin.hr 


\section{UVOD}

Marka predstavlja kombinaciju imena, dizajna ili simbola, pojma, usluga jednog ili nekoliko proizvođača kojom se diferenciraju od konkurencije (Kotler i sur., 2006). Pojam marki se razvijao kroz vrijeme i počeo poprimati sve veći značaj za potrošače oblikujući odnos temeljen na emocijama. Gotovo sve što se svakodnevno koristi u obliku generičkih proizvoda poput vode, automobila, kave, odjeće nalazi se pod okriljem neke marke.

Cilj ovog rada je koristeći relevantne izvore pokušati razjasniti razliku između dva važna konstrukta, marke i proizvoda te što podrazumijeva proces stvaranja marke. Također pobliže istražiti značaj kvalitete u procesu stvaranja uspješne marke i pozitivnih poslovnih rezultata i profita.

Proizvod je skup određenih karakteristika koje se mogu plasirati na tržište pod određenom markom, dok je sama marka više usmjerena na doživljaj i emocije na kojima se temelji odnos s potrošačima.

Različiti autori su se bavili istraživanjem kvalitete i njezine percepcije te koju ulogu ima u odlučivanju o kupovini i stvaranju uspješne marke (Chaudhuri (2002); Vranešević 2007; Anić i sur (2010); Olenski (2016); Šugrova i sur. (2017);

Zahtjev za kvalitetom star je koliko i ljudski rod. Prije više od četiri tisuće godina, u doba arapskih, babilonskih, egipatskih, židovskih, feničanskih i rimskih trgovaca cvjetao je sitni "biznis", obrt i trgovina. Hamurabi, kralj Babilona, prvi je pokušao uvesti red u poslovanje svojih poduzetnika, donijevši oko 2100. godine p.n.e. Zakon o zaštiti kupaca i malih poduzetnika od prijevara. Izvorni primjerak tog zakona, isklesan u mramoru koji se i danas čuva u muzeju Louvre u Parizu (Petar, 1996).

Razvoj novih tehnologija, proizvodnih procesa, odnosno tehničkih sustava i pojava investicijski vrlo intenzivnih djelatnosti, odnosno djelatnosti kojima su pridruženi značajni rizici (zračni promet, svemirski program, nuklearna energetika i sl.) doveli su do pomaka u filozofiji poslovanja. Od kontroliranja kvalitete, s jednostavnom odrednicom za ocjenu "dobar-loš" došlo se do osiguranja kvalitete, koje obuhvaća i preventivne djelatnosti na područjima koja bitno utječu na kvalitetu, rabeći dobivene podatke, raščlanjujući uzroke odstupanja, te povratnom informacijom utječući na ulazne parametre koji uzrokuju pogrešku.

\section{OBILJEŽJA MARKE I PROCES STVARANJA MARKE}

Marka podrazumijeva naziv, simbole i svim čulima zamjetne podražaji koji se povezuju sa značajkama proizvoda i uslugama te njihovim funkcionalnim ili psihološkim 
koristima (Vranešević, 2007, str. 10). Marka predstavlja kombinaciju imena, dizajna ili simbola, pojma, usluga jednog ili nekoliko proizvođača kojom se diferenciraju od konkurencije (Kotler i sur., 2006). Vrijednost marke podrazumijeva određenu vrijednost koju je potrošač spreman platiti više za proizvod obilježen određenom markom (Šerić, 2009). Gotovo sve što se svakodnevno koristi od strane potrošača od odjeće, hrane, automobila, vode se na tržištu nalazi pod okriljem neke marke (Hampf, Lindberg, 2011). Danas je nemoguće zamisliti svakodnevni život bez marki, posebice globalnih marki poput Apple-a, Coca - Cole, Samsung-a, itd.

Pojam marki i njihova važnost razvijale su se zajedno s potrošačem. Od označavanja stoke od kuda potječe naziv brand (branding, eng, označavanje, žigosanje) sve do današnjih dana kada ne samo da su sastavni dio svakodnevnog funkcioniranja već predstavljaju statusne simbole, održavaju karakter ili vjerovanja korisnika, uzrok su potrošačeve sreće ili frustracije. Marke ne obitavaju samo u fizičkom prostoru već i u mislima ljudi gdje ostavljaju mentalne otiske koji mogu probuditi osjećaj duboke povezanosti s markom, bazirane na kulturnim vrijednostima i osobnim iskustvima koje logotip marke predstavlja (Gad, 2005, str. 27,28).

Taylor (2003) smatra kako su pretpostavke uspješne izgradnje marke slijedeće:

- izgradnja odgovarajućeg identiteta s naglašenom ulogom naziva i simbola kao elemenata identiteta marke)

- postizanje odgovarajuće razine prepoznatljivosti - 3/4 ciljne skupine korisnika uz podsjećanje može prepoznati marku i njezine osnovne značajke

- utjecaj na osjećaje i razum potrošača - nužna je emotivna povezanost potrošača i marke temeljena na konačnoj koristi za potrošača i razumnim vrijednostima marke

Odnos potrošača i marki slojevit i kompleksan, a u slučaju lojalnih potrošača temelji se i na emocijama. Marka se sastoji od naziva i(ili) znaka marke, ali i ostalih elemenata, te aktivnosti koje proizvođači dodjeljuju nekom proizvodu. Opipljive vrijednosti marke poput logotipa, znakova, simbola jednako su važne kao i one neopipljive poput asocijacija, doživljaja, osjećaja (Rocco, 2015). S obzirom da je vizualni identitet nešto što je potrošačima potencijalno najčešća asocijacija uz marku, potrebno je definirati i pojam trgovački znak (eng, trade mark). Rocco (2015) definira trgovački znak kao razliku između proizvoda ili usluge nastale iz vlasništva te kao vidljivo obilježje identiteta marke.

U slučaju marke pravno se mogu zaštiti osnovne elemente prepoznatljivosti: naziv (ime, znak ili logotipom, tipografija (font koji se koristi), boja, slogan, dizajn ambalaže, zvučni logotip, maskota, itd. Rocco (2015) smatra kako je jedan od najznačajnijih elemenata marke sami naziv marke. Marke se mogu označavati 1) logotipom poput Orangine, Sprite-a, Cockte gdje se slova oblikuju na poseban način i upravo po izabranom 
fontu postaju prepoznatljiva; 2) zaštitnim znakom gdje se kombiniraju vizualni simbol i logotip npr. Pravna obilježja trgovinskog znaka su mnogostruka jer registrirani trgovinski znak poprima veću vrijednost i izbjegava se mogućnost plagiranja od strane konkurencije. Postoje različiti simboli koji se koriste uz trgovački znak u svijetu, a to su ${ }^{\circledR},(C)$ TM (www.trademarknow.com).

Korištenje ${ }^{\circledR}(\mathrm{R}$ u krugu, eng. registered) uz sami trgovački znak u svijetu se smatra dobrom praksom kojom se na jasan način daje do znanja da su određene riječi ili grafički detalji zaštićeni. Primjerice u Engleskoj je nezakonito koristiti ${ }^{\circledR}$ znak bez registracije, dok u drugim zemljama nije strogo regulirano već se smatra da korištenje navedenog znaka bez registracije je zavaravanje potrošača. Znak (C) (C u krugu, od engleske riječi copyright) označava zaštićeni trgovački znak ali prema međunarodnim konvencijama o autorskim pravima poput rimske konvencije. Znak TM (engleski trademark) koristi se kada je trgovački znak u procesu zaštite, tj. daje poruku da se trgovački znak planira zaštiti od strane poduzeća. Na prepoznatljivost marke utječe također i njezina prisutnost $u$ medijima. Sve veće marke, posebice globalne imaju i značajne marketinške budžete kako bi stalno bili prisutni na tržištu i u percepciji potrošača.

Odabir elemenata marke kojom će se postići prepoznatljivost zajedno sa ostalim marketinškim aktivnostima je također ključna u postizanju poznatosti marke, stvaranjem pozitivne percepcije i poticanja pozitivnih osjećaja. Prema Kelleru (2003) potrebno je uvažiti šest kriterija odabira elemenata marke od pamtljivosti do mogućnosti pravne zaštite navedene marke (Prikaz 1).

Prikaz 1. Kriterij odabira elemenata marke

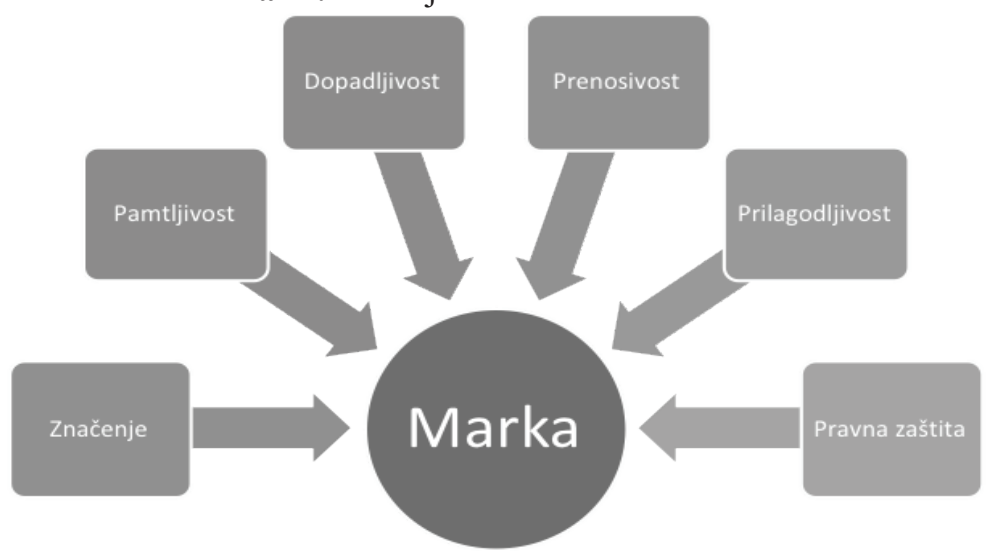

Izvor: Keller, L.K. (2003), Strategic Brand Management, Prentice Hall, str.176 
Navika korištenja od strane potrošača, imidž, omjer cijene i kvalitete su samo neke od koristi koje marke pružaju. Osim samih potrošača postoji još relevantnih dionika u samom procesu stvaranja marke poput vlasnika marke, dobavljača, distributera te šira javnost. Marke također mogu predstavljati puno više od onoga što se može pravno zaštiti te imaju svoju ulogu i važnost te se mogu promatrati kao iskaz vlasništva, sredstvo diferencijacije, funkcionalno i simboličko sredstvo, pravno i strateško sredstvo (Prikaz 2.).

Prikaz 2. Uloga i važnost marke



Izvor: Vranešević T, (2007), Upravljanje markama, Accent, Zagreb, str 15.

Kada se spominju marke vrlo često se spominju u kontekstu tržišne vrijednosti marke. Marka određuje dobra i usluge koji se razlikuju imenom ili dizajnom, što rezultira tržišnom vrijednošću marke. Šerić (2009) smatra kako marke danas predstavljaju najvrjedniju neopipljivu vrijednost imovine u poslovnom svijetu. Afridi (2013) smatra kako marke omogućavaju poduzećima strateške platforme za interakciju s potrošačima što u konačnici rezultira jakom financijskom vrijednošću. Postoji značajan broj globalno poznatih marki koje ulažu znatna sredstva u marketinšku komunikaciju kako zadržale postojeće i privukle nove potrošače.

U Hrvatskoj kao i području bivše Jugoslavije, nije uobičajeno objavljivanje vrijednosti pojedine marke. Mjeri se snaga marke gdje se mjeri prepoznatljivost marke, upotreba i iskustvo korištenja određene marke unutar specifične kategorije i dobiveni 
rezultati se zatim uzimaju u odnosu na ukupan broj stanovnika u državi (www.mediamarketing.com).

Tržišna vrijednost predstavlja ukupnu vrijednost marke i simbola koji je predstavlja, doprinosi tržišnoj konkurentnosti poduzeća koja je vlasnik marke te direktno utječe na vrijednost ostalih proizvoda istog poduzeća (Šerić, 2009). Kako bi marka postala prepoznatljiva, odnos s potrošačem započinje tako da potrošač mora donijeti odluku o korištenju marke. U odabiru marke, za potrošača postoje određeni rizici koje nastoji umanjiti različitim strategijama. (Prikaz 3.).

Prikaz 3. Strategije smanjenja rizika prilikom korištenja i odabira marke
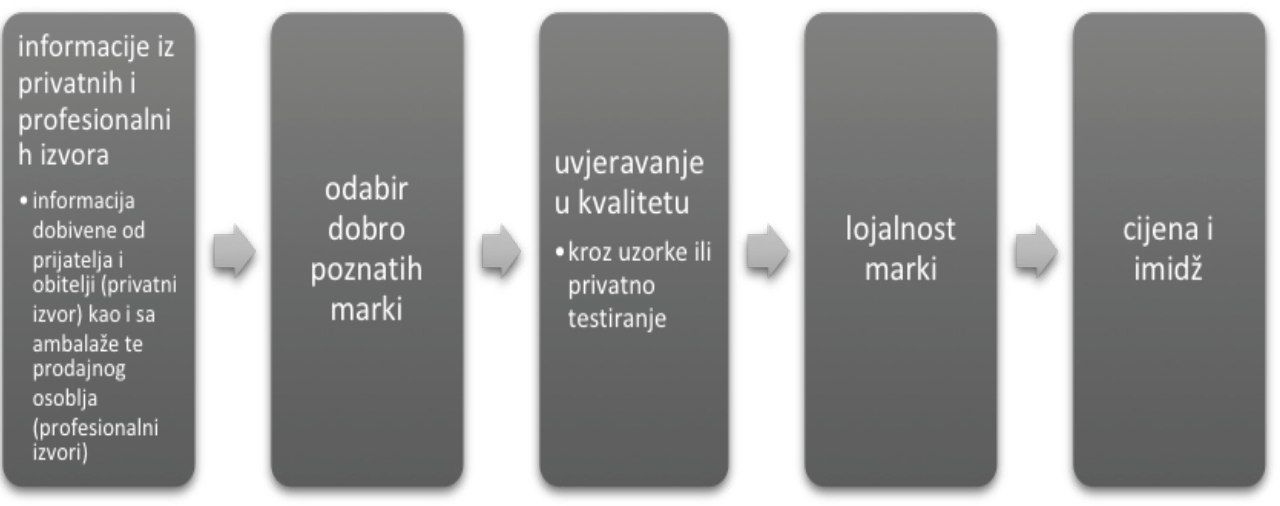

Izvor: Rubio, N. i sur., (2013), Brand awerness - Brand quality inference and consumers risk perception in store brands of food products, Food quality and preference, 32, str. 289 -298 .

Marke su potrošačima važne i sastavni su dio društva. Cilj svake marke je imati lojalne potrošače koji pozitivno utječu na njezin imidž, što u današnjem svijetu ubrzane komunikacije i mnoštva komunikacijskih platformi u vidu društvenih mreža može predstavljati određen izazov. Keller (2003) smatra kako se snaga marke može povezati sa percepcijom potrošača o samoj marci na temelju informacija koje su čuli o marci ili doživjeli, osjetili i primijetili. Potrošači više nego ikad se oslanjaju na vlastita iskustva s markom ili osoba u koje imaju povjerenja.

Chi i sur. (2009) naglašavaju kako sve veća svjesnost i informiranost potrošača uvelike utječe na usmjerenost prema poznatim markama pri kupovini. Macdoland i Sharp (2000) smatraju da je prepoznatljivost marke jedan od ključnih faktora pri odabiru marke od strane potrošača. Chi i sur. (2009) također navode, uzimajući većinom u obzir Aekerov 
model vrijednosti marke (koji obuhvaća lojalnost marki, poznatost marke, percipiranu kvalitetu, asocijacije na marku, ostale prednosti) da su uz svijest o marki ključni faktori u stvaranju marke i percepcija kvalitete marke, lojalnost marki i namjera kupovine:

- Svijest o marki - sastoji se od prisjećanja marke i prepoznavanja marke. Prisjećanje marke podrazumijeva da potrošači pri odabiru proizvoda znaju točno koje je marke. Prepoznatljivost marke znači da potrošači prepoznaju marku među drugim konkurentskim markama te je točno imenuju. Svijest o marki je ključan faktor pri odluci o kupovini.

- Percipirana kvaliteta marke - je subjektivan dojam potrošača na kojeg mogu utjecati prijašnja iskustva i osjećaju vezani za korištenje marke.

- Lojalnost marki - predstavlja polazišnu točku u izgradnji i uspješnosti marke. Aekerov model vrijednosti marke lojalnost marki povezuje s bazom lojalnih potrošača koji su ključni pri definiranju premium cijene kao i odolijevanju aktivnosti konkurencije.

- Namjera kupovine - potrošači imaju veću namjeru kupovine u slučaju poznatih marki prema kojima imaju pozitivne osjećaje.

Drugi istraživači su također bazirali svoja istraživanja na Aekerovom modelu vrijednosti. Severi i Ling (2013) u svojem su istraživanju proučavali ključne faktore u stvaranju vrijednosti marke, tj međusobnu povezanost asocijacije na marku, prepoznatljivost marke, percipiranu kvalitetu, lojalnost i imidž marke i došli do nekoliko zaključaka:

- $\quad$ u odnosu između prepoznatljivosti marke i vrijednosti marke ključna je asocijacija na marku

- u odnosu između asocijacije na marku i vrijednosti marke ključna je lojalnost marki

- u odnosu između lojalnosti marke i vrijednosti marke ključan je imidž marke

- u odnosu između imidža marke i vrijednosti marke ključna je percipirana kvaliteta

\section{KVALITETA PROIZVODA}

Proizvod je neizostavan dio marketinškog miksa i podrazumijeva materijalni rezultat procesa proizvodnje (Meler, 2005). Proizvodom se također smatrati sve što se može ponuditi tržištu, točnije potrošaču kako bi se zadovoljile određene potrebe ili želje. Proizvod u konačnici mora imati svoju komercijalnu vrijednost inače nema tržišnog potencijala, što može podrazumijevati ideju, događaj, uslugu, mjesto, itd. (Kotler, 2003). 
Proizvodom se također može podrazumijevati sve ono što je ponuđeno tržištu s ciljem da se zadovolje potrebe ili želje potrošača u procesu razmjene (Grbac, 2007). Osmisliti dobar i uspješan proizvod je zahtjevan i izazovan proces za svako poduzeće. Poduzeća odluku o novim proizvodima trebaju pomno donijeti nakon detaljnog istraživanja tržišta i konkurenata, te voditi računa i o ostalim elementima marketinškog miksa: cijene, promocije i distribucije.

Proizvode možemo svrstati u tri osnovne skupine koju čine: potrošni proizvodi koji se potroše u jednoj ili nekoliko upotreba (sladoled, kruh, čokoladica, itd.); trajni proizvodi koji se koriste dulje vremena (mobitel, kompjuter, obuća, odjeća, itd); usluge koje predstavljaju djelatnosti ili koristi koje su namijenjene prodaji (korisnički paket kabelske televizije ili teleoperatera, turistički aranžman). (Prikaz 4.)



Izvor: Meler, M. (2005), Osnove marketinga, Ekonomski fakultet u Osijeku, str 179.

Meler (2005) smatra kako se proizvodi mogu koristiti u različite svrhe, tj. imaju različitu frekvenciju korištenja: neki se kupuju često (kruh, mlijeko), neki povremeno (vitamini, lijekovi, mali kućanski aparati), u slučaju nužde (vatrogasni aparati, pojas za spašavanje), u slučaju impulzivne kupovine (sladoled, čokoladice, žvakaće gume).

Rocco (2015) navodi kako razvoj novih proizvoda u većini većih poduzeća provodi odjel za istraživanje razvoj. Postoje tri osnovna smjera razvoja proizvoda: 1) razvoj izvornih proizvoda koji su potpuna novost na tržištu (Sumamed, Tesla električni automobil), 2) poboljšanja u proizvodima u smislu funkcionalnog inoviranja postojećeg 
proizvoda (Cedevita s chia sjemenkama; 3) modifikacije, redizajn proizvoda ili marki (Rocco, 2015). Uz razvoj novih proizvoda moguća je kupnja patenta, cijele tvrtke ili licence pa se na taj način stječe vlasništvo nad postojećom markom ili proizvodom te smanjuje rizik stvaranjem novih proizvoda ili marki već se ulaže u poznat i etabliran proizvod ili marku.

Razvoj novog proizvoda je značajan pothvat koji iziskuje vrijeme, kapacitete i novac. Prilikom razvoja novog proizvoda unutar poduzeća formira se projektni tim gdje se imenuje voditelj i dodijele ostala zaduženja. Postoje određeni koraci u razvoju novih proizvoda, definiranje strategije, generiranje ideja, pregledavanje ideja, razvoj i testiranje koncepcija, marketinška strategija, poslovna analiza, razvoj i dizajn proizvoda, probni marketing, komercijalizacija (Rocco, 2015 prema Kotler i sur. 2006).

U današnji brzi način poslovanja, velike konkurencije i nadasve informiranog potrošača razvoj novog uspješnog proizvoda predstavlja izazov za svako poduzeće. U svrhu ostvarivanja tržišnih udjela i/ili boljih poslovnih rezultata od strane donose se odluke o proizvodnji proizvoda bez da se dovoljno ispita tržište i konkurencija od strane poduzeća. Poduzeća se uzdaju u jačinu marke pod kojim se proizvod plasira na tržište i da će tržište na taj način lakše prihvatiti proizvod kako bi se uštedilo na troškovima. Potrošač će na temelju prepoznatljivost marke kupiti proizvod jednom, ali ukoliko nije zadovoljavajući, do ponovne kupnje neće doći.

Iznimno uspješni proizvodi i marke su vrlo rijetki i rezultat su pažljivog planiranja, istraživanja tržišta, prepoznavanja želja i potreba potrošača, a ponekad i spremnost na rizik.

U vrijeme društvenih mreža, moć utjecaja na potrošače je prešla iz ruku marki u ruke samih potrošača koji formiranjem grupa na društvenim mrežama međusobno komentiraju svoje zadovoljstvo ili nezadovoljstvo sa određenim proizvodima, uslugama i markama pod čijim su okriljem plasirana na tržište (Bernoff, Li, 2008). Internet je pružio potrošačima mogućnost da sami postanu medij komunikacije o novim proizvodima i markama, dijeleći svoja iskustva i doživljaje o korištenju određenih proizvoda i time aktivno doprinoseći njihovom uspjehu ili neuspjehu (Leung i sur., 2013). Upravo u današnjem ubrzanom digitalnom svijetu, kvaliteta proizvoda i usluga ima dodatan značaj u izgradnji uspješnih marki.

Olenski (2016) smatra kako je koncept kvalitete vrlo jednostavan; bilo da je riječ o proizvodu ili usluzi uvijek se radi o odnosu vrijednosti za kupljeno i ispunjavanja očekivanja potrošača.

Kvaliteta proizvoda ili usluge odnosi se na percepciju stupnja prema kojem proizvod ili usluga ispunjava očekivanja kupaca. Šugrova i sur. (2017) napominju kako potrošači kvalitetu proizvoda percipiraju i kroz kvalitetnu ambalažu i atraktivan vizualan identitet. Stupanj zadovoljstva kupca izravno utječe na to kako se određuj kvaliteta 
proizvoda ili usluge. Kvaliteta je postala strateški cilj gotovo svakog poduzeća. Postavljaju se sve veći zahtjevi od strane tržišta za kvalitetom proizvoda i usluge; kvalitetom proizvodnih i poslovnih procesa; pouzdanošću cjelokupnog sustava kvalitete. (Prikaz 5.)

Prikaz 5. Zahtjevi tržišta za vrstama kvalitete u poslovanju
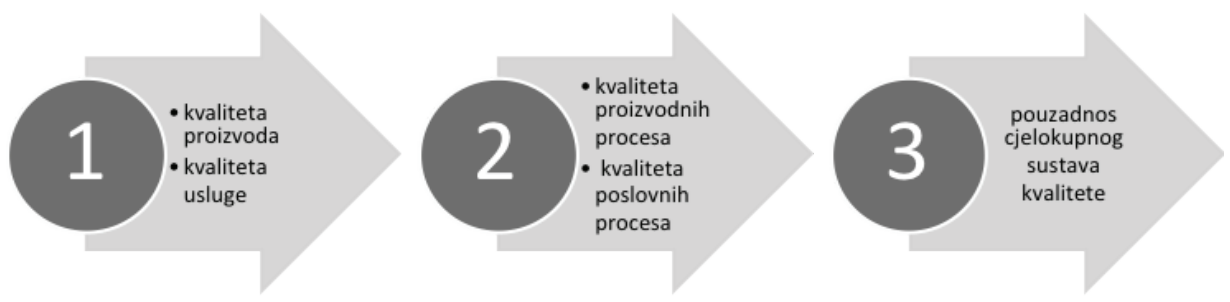

Izvor: Lazibat, T (2003), Sustavi kvalitete i hrvatsko gospodarstvo, Ekonomski pregled, $54(1-2)$, str 56.

Sustav upravljanja kvalitetom povećava performanse cijelog poslovnog sustava, smanjuje troškove, povećava i olakšava upravljanje, poboljšava odnose s potrošačima te omogućuje poduzećima konkuriranje na globalnom i prednost pred konkurencijom. (Šuman i sur., 2013). Standardi kvalitete koje poduzeće posjeduje također imaju značajan utjecaj na uspješnost samog proizvoda. Kvaliteta je danas postala primaran i strateški cilj gotovo svakog poslovnog subjekta (Lazibat, 2003, str. 55). Standardi kvalitete omogućavaju organiziranost i red u korištenju proizvoda i usluga te su integrirani u proizvode koje koristimo svakodnevno poput električne energije ili ,pametnih“ telefona (Šerić, 2009). Standardi kvalitete za poduzeća znače potvrdu kvalitete koju poduzeće kroz svoje proizvode i usluge nudi svim dionicima tržišta poput kupaca, dobavljača, distributera, itd. (Petar, 1996.). Postoje međunarodni propisani standardi za pružatelje usluga WIFI -a (IEEE standard), aplikacije (ECMA i ISO standard za Java enkripciju), Internet (W3C standard), itd. (www.etsi.org).

Lazibat (2003) smatra kako ostvarivanje kvalitete proizvoda ima različite pozitivne učinke za poduzeće, a koje je nadalje moguće korelirati i sa uspješnošću marke:

- $\quad$ povećanje prodaje (realizacije) zahvaljujući zadovoljstvu potrošača

- smanjenje troškova (manje povrata i reklamacija na proizvod i/ili uslugu)

- optimalna proizvodnja

- usklađenost svih dionika poslovnog sustava

Proizvod može imati različita obilježja kvalitete, tj. zahtjeva koje je potrebno ispuniti. Važnija obilježja mogu biti klasifikacijska, funkcionalna, konstrukcijska, 
tehnološka, ekonomska, obilježja pouzdanosti i unifikacije, ergonomska obilježja, obilježja sigurnosti i ekološka obilježja, estetska obilježja (Petar, 1996). Navedena obilježja možemo podijeliti u dvije skupine: tehnička i tehnološka obilježja.

Tehnička obilježja proizvoda su:

- Klasifikacijsko obilježje svrstava proizvod u određenu skupinu poput aromatizirane vode, dodataka prehrani, proizvodi sa smanjenim udjelom šećera, itd.

- Funkcionalna obilježja podrazumijevaju najvažnija svojstva proizvoda poput namjene, određenih pogodnosti i ograničenja uporabe

- Konstrukcijska obilježja podrazumijevaju oblik proizvoda, strukturu, primijenjene materijale

Tehnološka obilježja proizvoda su:

- Obilježja koja karakteriziraju tehnologiju izrade proizvoda i njezinu djelotvornost, dok druga obilježja čine zahtjevi u samom procesu stvaranja

- Ekonomska obilježja koja podrazumijevaju ekonomičnost i rentabilnost, marketinšku i poslovnu rentabilnost

- Pouzdanost kao obilježje podrazumijeva da proizvod radi određeno vrijeme bez kvara

- Popravljivost - mogućnost da se proizvod dovede iz neispravnog u ispravno stanje

- Trajnost - održavanje funkcionalnosti u određenom vremenskom periodu

- Obilježja unifikacije - udio unificiranih i izvornih dijelova u nekom proizvodu

- Ergonomska obilježja - zahtjevi koje određeni proizvod mora zadovoljavati (higijenski, fiziološki, itd.)

- Obilježja sigurnosti - zaštita na radu

- Ekološka obilježja - utjecaj koji proizvod ima na okoliš

- Estetska obilježja - vizualni izgled proizvoda uvelike može utjecati na njegovu konkurentnost

- Patentno - pravna obilježja - mogućnost zaštite od plagijata na tržištu

Razinu kvalitete poslovanja poželjno je postupno postizati, a standardi kvalitete mogu biti državni ili međunarodni. Kako su današnji potrošači sve zahtjevniji i educiraniji, te bolje povezaniji kroz Internet i društvene mreže, osim vidljivih karakteristika kvalitete samog proizvoda zanimaju ih garancije kvalitete koji nisu vidljive. Lazibat (2003) smatra kako suvremeni pristup kvaliteti treba osigurati ispunjenje zahtjeva korisnika kako će dobavljač isporučivati proizvode i/ili usluge ujednačene kvalitete. Lazibat (2003) također navodi kako certifikati kvalitete propisuju način na koji 
se treba odvijati poslovanje poduzeća, tj odjele koji trebaju osigurati kvalitetu u svojem djelovanju. Sukladno navedenom poduzeća trebaju osigurati kvalitetu u marketingu; kvalitetu pri ponudi (osigurati kvalitetu tijekom ostvarenja projekta i u odnosu s kupcima); kvalitetu u nabavi; kvalitetu u planiranju proizvodnje i u samoj proizvodnji (kontrola proizvodnog procesa, i završne kontrole i ispitivanja); osiguranje kvalitete $u$ isporuci; upravljanje dokumentacijom; audit (nadzor nad funkcioniranjem sustava kvalitete); troškovi kvalitete.

Najpoznatiji međunarodni certifikat kvalitete je ISO 9000 koji uvođenjem od strane poduzeća kupcima pokazuje da se poduzeće pridržava preuzetih obaveza te zadovoljenja njihovih potreba za kvalitetom proizvoda ili usluga. Certifikat ISO 9000 poduzeća mogu implementirati bez obzira kojom vrstom djelatnosti se bave ili broja zaposlenika koje imaju. Poduzeća se mogu baviti od razvoja i istraživanja do proizvodnje i pružanja usluga. Uvođenjem ISO 9000 može imati niz prednosti za poduzeće od troškova kontrole kvalitete, unapređenja kvalitete i boljeg iskorištavanja sredstava. To je certifikat koji potvrđuje da poduzeće raspolaže organizacijom koja sadrži sustav za osiguranje kvalitete (Petar, 1996).

\section{ODNOS KVALITETE I STVARANJA MARKE}

Vranešević (2007) smatra kako svaka marka ima opipljivu i neopipljivu vrijednost marke. Opipljiva vrijednost marke izražava se u financijskoj vrijednosti, dok je neopipljiva vrijednost marke podrazumijeva odnos potrošača i marke.

Startain i Schuman (2006) smatraju kako je možda najveća moć marke osjećaj koji stvara pri korištenju za potrošača i dugotrajni odnos koji se stvara između marke i potrošača temeljen na lojalnosti i povjerenju.

Marke se često smatraju sinonimom za kvalitetu jednako kao i statusnim simbolom za pojedince i grupe. Upravljanje kvalitetom proizvoda i usluga od strane marki šalje signal da je svaki kupac, potrošač ili korisnik jednako važan. Moguće je zaključiti kako marke imaju vlastitu vrijednost u društvu te da poduzeća u čijem su marke vlasništvu kao prioritet trebaju imati pružanje kvalitetnih proizvode i usluga tržištu. Također se može zaključiti kako ujednačena kvaliteta proizvoda je ključna pri stvaranju uspješne marke, posebice u stvaranju baze lojalnih potrošača marke. Chaudhuri (2002) smatra kako je percepcija kvalitete marke značajan faktor koji utječe na odluku o kupovini.

Potrošači, proizvođači i društvo u cjelini vrlo imaju različitu percepciju kvalitete. Vranešević (2007) navodi kako potrošači proizvod ili uslugu koji su predstavljeni raznim 
markama doživljavaju kao proizvode i usluge različite kvalitete. Doživljena kvaliteta pridonosi vrijednosti marke jer je često osnovni razlog kupovine.

Potrošači skloni kvaliteti imaju visoka očekivanja i nisu zadovoljni s , prosječnim“ proizvodom koji se nudi na tržištu, te stoga traže proizvode najbolje kvalitete, tražeći dostupne informacije o ponuđenim proizvodima i u konačnici donose odluku o kupovini proizvoda visoke kvalitete. (Anić i sur., 2010, str,140). Anić i sur. (2010) također navode kako je moguće potrošačevu percepciju kvalitete definirati kao subjektivan dojam karakteristika određenog proizvoda ili usluge dok je sklonost odabiru marki odraz potrošačeve sklonosti prema kupovini poznatijih i skupljih marki. Potrošači percipiraju marku kao skup određenih informacija o proizvodu na temelju kojih donose subjektivne zaključke o kvaliteti određenog proizvoda i/ili marke. Borković (1996) smatra kvalitetu ključnim dijelom uspješnog poslovnog procesa na koju utječu očekivanja kupaca/potrošača i stvarno poslovanje. (Prikaz 6.)

Prikaz 6. Model sustava upravljanja kvalitetom



Izvor: Borković V. (1996), Strategije razvoja i kvaliteta ponude u hotelijerstvu, Tour.hosp.manag. Vol. 2, No. 1, str.27.

Pojam kvalitete potrošači i proizvođači različito definiraju. Za potrošače to podrazumijeva kvalitetu dizajna, cijenu dok je za proizvođača to kvaliteta sukladna specifikaciji i trošku. (Prikaz 7.) 
Prikaz 7. Značenje pojma kvalitete
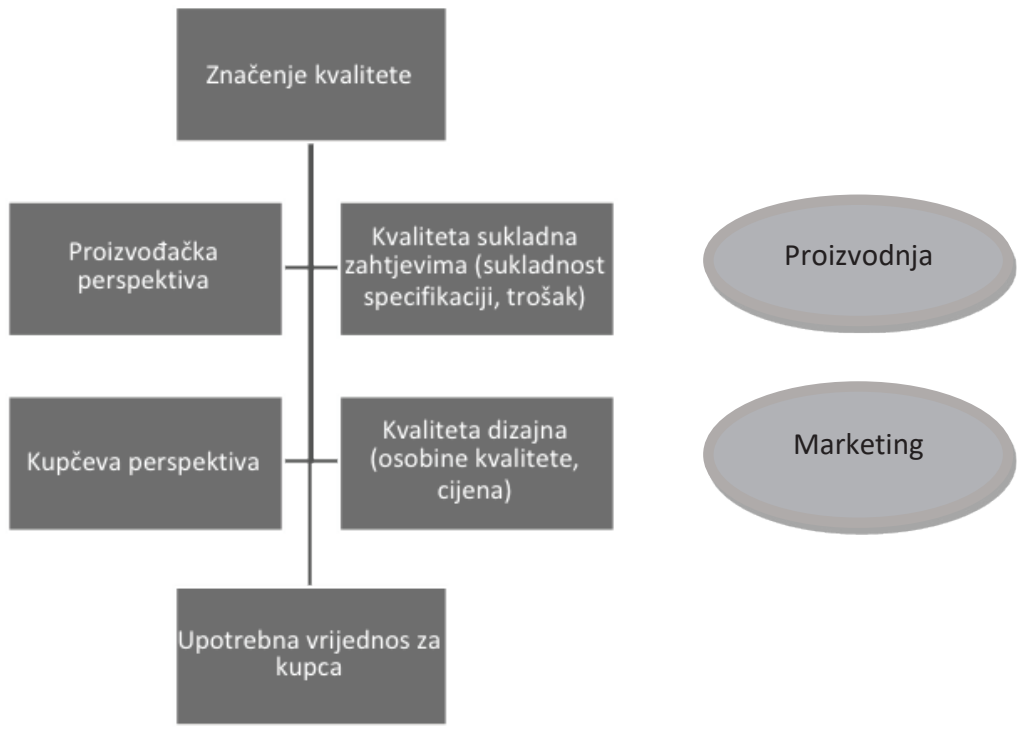

Izvor: Gaži - Pavelić, K., Upravljanje sustavom kvalitete i rizicima. Osnove najbolje poslovne prakse za mala i srednja poduzeća, Hrvatski zavod za norme. Dostupno na https://www.mingo.hr/public/documents/95-vodic-kvaliteta-i-rizici.pdf, pristupljeno 5.5.2019.

Kvaliteta marke ima dvije dimenzije: razinu kvalitete i dosljednost kvalitete (Rocco, 2015). Razina kvalitete podrazumijeva svojstva marke i, ili proizvoda koje potrošač od nje očekuje), dok dosljednost jamči da je kvaliteta uvijek na istoj razini. Predodžba kvalitete je temelj strategije povjerenja prema marci. Mnoge velike marke kvalitetu uključuju u svoju i misiju i kao temelj pozicioniranja na tržištu. Postoje cjenovne marke i prestižne (premium) marke.

Stvaranje jakih i prepoznatljivih marki je kompleksan i dugotrajan zadatak na koje utječu interni i eksterni uzroci. Šerić (2009) smatra kako postoje osam temeljnih činjenica koje mogu otežati stvaranje jake marke: težnja konkuriranju cijenom; širenje i rast konkurencije; povijesni razvoj tržišta; kompleksnost strategije marke (marke, podmarke, samostalne sastavnice marke, proširene marke, usvojene marke i korporacijske marke); sklonost promjeni i modifikacijama strategija; sklonost i rizici inoviranja; tendencije portfeljnog poslovanja tvrtki; kratkoročno razmišljanje. Afridi (2013) smatra kako je kvaliteta važna komponenta uspjeha svake marke, koja rezultira 
zadovoljstvom potrošača, njihovom lojalnošću i u konačnosti profitabilnošću. Na današnjem tržištu marke da bi ostale ili postale velike moraju voditi računa da potrošači imaju toliki izbor pri donošenju odluke o kupovini. Kako bi marka postala uspješna, percepcija kvalitete jedna je od ključnih komponenti uspjeha koja se temelji na subjektivnom dojmu potrošača na temelju ideja, iskustva i informacija koje potrošač ima o marki. Stvoriti uspješnu marke iznimno je zahtjevan i izazvan proces za poduzeće. Proizvod postaje marka. tek kada za potrošača ima određenu vrijednost, tj. kada se uspostavi odnos s markom koji se temelji na emocijama. Percepcija o kvaliteti marke često je subjektivne prirode temeljena na prethodno dostupnim informacijama $\mathrm{i}$ iskustvima potrošača.

\section{ZAKLJUČAK}

Marka i proizvod se dva različita konstrukta gdje pojam marke podrazumijeva naziv, simbole i čulima zamjetne podražaje koje utječu na doživljaje i emocije kojima se potrošač veže za marku. Proizvod s druge strane se smatra materijalnim rezultatom proizvodnje i skup određenih karakteristika poput kvalitete, pouzdanosti, sigurnosti, cijene i kao takav se plasira na tržište pod okriljem određene marke.

Marke su sastavni dio čovjekove svakodnevnice i odražavaju životni stil i preferencije potrošača koji ih koriste. Potrošači se vežu za marke, pa tako voze određenu marku automobila, piju određenu vrstu kave, nose određenu marku odjeće i obuće i gotovo sve što se danas svakodnevno koristi se može naći pod okriljem određene marke.

Odluku o novom proizvodu poduzeće treba donijeti pažljivo, s ispitanim tržištem, njegovim potrebama i navikama jer u konačnici proizvod mora imati komercijalnu vrijednost inače nema tržišni potencijal. Nije dovoljno proizvod plasirati na tržište pod okriljem poznate marke, jer takav proizvod ima vrlo nesigurnu budućnost. Potrošači žele kvalitetu koja zadovoljava njihove potrebe i želje. Potrošači kojima je kvaliteta važna imaju visoka očekivanja i nisu zadovoljni s ,prosječnim“ proizvodom koji se nudi na tržištu. Plasmanom nekvalitetnog proizvoda na tržište može se ozbiljno narušiti imidž marke.

Koncept kvalitete zapravo vrlo jednostavan; bilo da je riječ o proizvodu ili usluzi uvijek se radi o dobivenoj vrijednosti za kupljeno i ispunjenju očekivanja potrošača. Kvaliteta je također postala strateški cilj gotovo svakog poduzeća posebice jer se postavljaju sve veći zahtjevi od strane tržišta za kvalitetom proizvoda i usluge; kvalitetom proizvodnih i poslovnih procesa i pouzdanošću cjelokupnog sustava kvalitete. Sustav upravljanja kvalitetom koji podrazumijeva uvođenje standarda kvalitete povećava performanse cijelog poslovnog sustava, smanjuje troškove, povećava i olakšava 
upravljanje, poboljšava odnose s potrošačima te omogućuje poduzećima konkuriranje na globalnom i prednost pred konkurencijom. Standardi kvalitete koje poduzeće posjeduje imaju značajan utjecaj na uspješnost samog proizvoda. Omogućavaju organiziranost i red u korištenju proizvoda i usluga te su integrirani u proizvode koje koristimo svakodnevno poput električne energije ili „pametnih“ telefona. Ujednačena kvaliteta je ključna pri stvaranju uspješne marke, posebice u stvaranju baze lojalnih potrošača marke. Percepcija kvalitete marke također je značajan faktor, često subjektivne prirode temeljen na iskustvima potrošača koja utječu na odluku o kupovini, posebice jer potrošači, proizvođači i društvo u cjelini imaju vrlo različitu percepciju kvalitete. Može se zaključiti kako je kvaliteta važna komponenta uspjeha svake marke, koja rezultira zadovoljstvom potrošača, njihovom lojalnošću i u konačnici profitabilnošću.

\section{LITERATURA:}

1. Afridi, A. (2013), The success of global brands: A quality and price perspective, Journal od strategy \& performance management, 1(1), str 16-23. Dostupno na https://pdfs.semanticscholar.org/c2d4/e166903b92c623c2260cdb8a625f0f6594 cd.pdf, pristupljeno 20.09.2019.

2. Anić, I.-D., Piri-Rajh, S., Rajh, E. (2010), Utjecaj kvalitete i cijene na lojalnost marki, Ekonomski pregled, 61 (3-4), str 137-150, str. 140. UDK 339.13:658.62.018.2(497.5)

3. Bernoff, J., Li, C., (2008). Harnessing the Power of the Oh-So-Social Web. MIT, SLoan Management review 49(3), str. 36-42. Dostupno na https://sloanreview.mit.edu/article/harnessing-the-power-of-the-ohsosocialweb/, pristupljeno 20.09.2019

4. Borković V. (1996), Strategije razvoja i kvaliteta ponude u hotelijerstvu, Tour.hosp.manag. Go.2 br. 1, str 25-31, str.27

5. Chaudhuri, A. (2002). How brand reputation affects the advertising - brand equity link. Journal of advertising research, 42(3), str. 33-43, https://doi.org/10.2501/jar-42-3-33-43.

6. Chi, H.K., Yeh, H.R., Yang, Y.T. (2009), The impact of brand awerness on consumer purchase intetnion: The mediating effect of percieved quality and brand loyalty. The journal of international management studies, 4(1), str.135144.

Dostupno

na https://pdfs.semanticscholar.org/ea96/5086eeac9584e4a679a04a518a148351e7 87.pdf, pristupljeno 15.09.2019 
7. Gad, T. (2005), 4-D Branding, Razbijanje korporacijskog koda mrežne ekonomije, Differo, Zagreb, str 27,28.

8. Gaži - Pavelić, K., Upravljanje sustavom kvalitete i rizicima. Osnove najbolje poslovne prakse za mala i srednja poduzeća, Hrvatski zavod za norme. Dostupno na https://www.mingo.hr/public/documents/95-vodic-kvaliteta-i-rizici.pdf, pristupljeno 5.5.2019.

9. Grbac, B. (2007), Načela marketinga. Rijeka : EFRI.

10. Hampf, A., Lindberg-Repo, K. (2011). Branding: The Past, Present, and Future: A Study of the Evolution and Future of Branding. Hanken School of Economics Working Papers. (Dostupno na https://helda.helsinki.fi/bitstream/handle/10138/26578/556_978-952-232-1343.pdf. pristupljeno: 21.4.2019).

11. https://www.etsi.org/images/files/Education/Understanding_ICT_Standardizati on_LoResWeb_20190226.pdf, pristupljeno 13.5.2019.

12. https://www.trademarknow.com/support/faq/registered-trademark-symbol, pristupljeno 13.5.2019.

13. Keller, L.K. (2003), Strategic Brand Management, Prentice Hall, str.176.

14. Kotler, P., Wong, V., Saunders J., Armstrong, G. (2006), Osnove marketinga, Mate, Zagreb.

15. Lazibat, T. (2003), Sustavi kvalitete i hrvatsko gospodarstvo, Ekonomski pregled, 54 (1-2), str 55-76.

16. Leung, D., Law, R., Van Hoof, H., Buhalis, D. (2013), Social Media in Tourism and Hospitality; a literature review, Journal of Travel \&Tourism Marketing, vol 30, str 3-22. DOI: 10.1080/10548408.2013.750919

17. Macdonald, E.K., Sharp, B.M. (2000), Brand awerness effects on consumer desicion making for a commonm repeat purchase product: A replication, Journal of Business Research, 48, str. 5-15. DOI: 10.1016/S0148-2963(98)00070-8

18. Meler, M. (2005), Osnove marketinga, Ekonomski fakultet u Osijeku, ISBN 953-6073-94-3.

19. Najjači brandovi u zemljama regije (2016). Dostupno na https://www.mediamarketing.com/vijesti/najjaci-brendovi-u-zemljama-regije/, pristupljeno 12.5.2019.

20. Olenski, S. (2016), Why brands must never lose sight of quality, dostupno na https://www.forbes.com/sites/steveolenski/2016/11/16/why-brands-mustnever-lose-sight-of-quality/\#29bc418e6147, pristupljeno 24.09.2019.

21. Petar, S. (1996), Uvod u upravljanje kvalitetom, Nading, Zagreb.

22. Rocco, S. (2015), Upravljanje proizvodom, kreiranje marke i dizajn, Visoka poslovna škola Zagreb, ISBN 978-953-57657-5-2, dostupno na 
https://pvzg.hr/wp-content/uploads/2018/08/Rocco-S-PROIZVOD-I-DIZAJNskripta.pdf, pristupljeno 13.5.2019.

23. Rubio, N., Oubina, J., Villasenor N. (2013), Brand awerness - Brand quality inference and consumers risk perception in store brands of food products, Food quality and preference, 32, str. 289 - 298. DOI: 10.1016/s0148-2963(98)000708 .

24. Sartain, L.,Schumann, M. (2006). Brand from the inside: Eight essentials to emotionally connect your employees to your business. San Francisco: JosseyBass.

25. Severi, E., Ling, K.C (2013), The mediating effects of brand association, brand loayalty, brand image and percieved quality on brand equity, Asian Social Science, 9(3), https://doi.org/10.5539/ass.v9n3p125.

26. Šerić, N. (2009), Razvoj i dizajn proizvoda i upravljanje markom, Sveučilište u Splitu, Ekonomski fakultet Split, ISBN: 978-953-281-022-6.

27. Šugrova, M., Šedik, p., Kubelkova, A., Svetlikova V. (2017), Impact of product quality on consumer satisfaction and corporate brand, Economic Annals - XXI (165) (5-6):133-157, https://doi.org/10.21003/ea.V165-27.

28. Šuman, S., Kovačević, A., Davidović, V. (2013), Norme kvalitete - još uvijek neiskorišten potencijal. Zbornik Veleučilišta u Rijeci. Vol 1., No.1, pp 291-306.

29. Taylor, D. (2003), The Brandgym - A Practica Workout for Boosting Brand and Business, John Wiley \& Sons, Ltd. ISBN: 0-470-84710-7.

30. Vranešević, T. (2007), Upravljanje markama, Accent, Zagreb, str 10. 


\title{
PRODUCT QUALITY AS AN IMPORTANT FACTOR IN BRAND BUILDING
}

\author{
Saša Petar \& Tajana Marušić
}

\section{Summary:}

Brand-consumer relationship is complex and sensitive because brands often reflect consumers' opinions and attitudes. Consumers establish a relationship based on emotions with brands and expect that certain important characteristics that they associate with a brand do not change. In particular, they expect continuity in quality, which is considered to be one of the key determinants of building a successful brand. In today's extremely fast and competitive market, it is more important for brands than ever to maintain continuity of quality and thus meet consumer expectations. The aim of this paper is to explain in more detail the characteristics of a brand, as well as the difference between a brand and a product, and the process of building a brand itself. By reviewing the available and current literature, this paper also aims to examine more closely the importance of quality in the process of creating a successful brand, which then generates positive business results and profits.

Key words: brand, product, quality. 